\title{
Study the effect of the painted look in the works of illustration of iranian painter artists
}

\section{Fereshteh Fathalizadeh Kalkhoran ${ }^{1}$ and Behnam Kamrani ${ }^{2}$}

\author{
1 Department of Graphic, Central Tehran Branch, Islamic Azad University, Tehran, Iran. \\ E-mail: fereshtehfathalizadeh@gmail.com \\ 2 Assistant Professor, University of Tehran, Tehran, Iran. \\ E-mail:kamranib@gmail.com
}

\begin{abstract}
Modern painting in Iran seems dynamic and energetic at first glance; however, some believe that it's alien to Iranian national Identity and some others believe it has led to identity crisis. Painting and portraiture has undergone considerable changes. The importance of these changes, characteristics and functions, lead to our research goal. Research goal: to study the effects of artistic view in portraiture works of for Iranian painters: Ali Akbar Sadeghi, Mohammad Ali Bani Asadi, Karim Nasr and Farshidshafiei. Research method: The method used in this study is descriptive-analytic. Collecting data: The way to collect data is documentary and field research. Findings: Findings show that there is no significant difference between these two arts in many artistic works of modern painters and sometimes they overlap. Moreover, considering national Identity, painters have tried to modernize painting by the use of modern art methods. They have combined traditional art factors with western modern painting experience, added by national belief to create a kind of harmony and balance between these two arts.
\end{abstract}

Keywords: Painting. Illustration. Artists. Iranian painter.

Estudo do efeito do olhar pintado nas obras de ilustração de artistas de pintores iranianos RESUMO: A pintura moderna no Irã parece dinâmica e energética à primeira vista; no entanto, alguns acreditam que é alheio à identidade nacional iraniana e outros acreditam que isso levou a uma crise de identidade. Pintura e retratos sofreram mudanças consideráveis. A importância dessas mudanças, características e funções leva ao nosso objetivo de pesquisa. Objetivo da pesquisa: estudar os efeitos da visão artística em retratos de pintores iranianos: Ali Akbar Sadeghi, Mohammad Ali Bani Asadi, Karim Nasr e Farshidshafiei. Método de pesquisa: O método utilizado neste estudo é descritivo-analítico. Coleta de dados: A maneira de coletar dados é documental e pesquisa de campo. Resultados: Os resultados mostram que não há diferença significativa entre essas duas artes em muitos trabalhos artísticos de pintores modernos e, às vezes, eles se sobrepõem. Além disso, considerando a identidade nacional, os pintores tentaram modernizar a pintura pelo uso de métodos de arte moderna. Eles combinaram fatores de arte tradicionais com a experiência de pintura moderna ocidental, acrescentados pela crença nacional para criar uma espécie de harmonia e equilíbrio entre essas duas artes.

Palavras-chave: pintura, ilustração, artistas, pintor iraniano 


\section{INTRODUCTION}

Choosing the angles of view of an artist, in drawing and illustrating and creating an art, irrespective of its positive functions, in particular, in order to better transfer the artist's concepts and messages to the audience, has different ways that with the scientific knowledge of the functions of each of them, a new window to the world of contacts can be opened and in this way, it also promoted the quality of the works of artists. Illustration or illustration is a kind of illustrative and explanatory art. It may be the general purpose of an illustrator, to understand or to captivate a subject from a text. But it is not necessary to have a regular image in the text (PAKBAZ, 2001, 532).

Some of the outstanding painter artists in our country, in addition to their work in the field of painting, gave great visuals. In the present study, a brief account of what has been commonly used in illustration has been pointed out then the angles of different views of the painting look at the works of illustration of Iranian painter artists have been analyzed and along with it, the works of several artists in Iran, both in the field of painting and in the field of artistic illustration, have been investigated. Although the viewing angle is different in the illustration, but in these works, the artist often focuses on the direct, more coherent, and more transparent view of the nose.

\section{PROBLEM STATEMENT}

Perhaps today, the boundary between arts has undergone a tangible change due to the change in their media usage. The border, which sometimes is very shaky and pale. Understanding the fashions and methods of painting in contemporary Iranian imagery and how Iranian painters and how much they use the language and style of painting in their works of illustration is always a concern of Iranian artists.

We need a conceptual framework to accommodate various aspects of today's aesthetics (AHMADI, p. 44). The artist's choice affects media usage and features, and the concept of it undergoes a contemporary philosophical change. In this way, new trends in the media of art are born that emphasize the conceptual contradiction, form and narrative in the works produced. While institutions can play a role in this transformation.

The importance of the evolution, features, and uses of the newly created art of painting and illustration (in their similarity and difference) in contemporary art, in the form of a case study and an analysis of it, can make it possible to understand the art of today. In that sense, how the shape and process of the effects of these developments can create a new attitude in the way of presenting works.

One of the features that have taken place in the process of painting and contemporary illustration in the last decade is the attention to new materials and fashions in execution. In many cases, transparent and imaginative colors are also part of the presentation style, or the use of semantic collages and multiple layers on a single surface and the use of different ways in one effect and on the other. Eclectic practices are also similar to those of contemporary painting and painting. That is, they do not believe in the narrative, and in a symbolic and metaphorical way they have adopted a more conceptual approach.

Some of the illustrators of the eighties at 
the beginning of their work were influenced by the works of Iranian pioneers in the $40 \mathrm{~s}$ and 50s, But after a few experiments, they moved away from those styles and moved to a new style of choice (QA'INI, p. 166).

\section{ANALYSIS METHOD}

Matching data, reports and information on the similarities and possible differences between imagery and contemporary painting in the form of aesthetics and formalism as well as the content of the works.

\section{A REVIEW OF IRANIAN IMAGINATION FROM THE PAHLAVI PERIOD TO THE CON- TEMPORARY PERIOD}

The establishment of the Academy of Fine Arts in 1941 and the establishment of the Faculty of Fine Arts by Andre Godard in 1946, as well as the study of a number of students in Europe, led to the growth of the art of illustration in Iran.

Ali Mohammad Heydarian, a painter and professor, was one of Kamalolmolk's students and a group of activists who founded the Faculty of Fine Arts, who was trained by a number of children's illustrators in his school. Among his most prominent and earliest students are Mahmoud Javadipour and Lily Taghipour, who at that time were involved in illustrating books and children's publications. Another student of Kamal alMulk, Mohammad Nasser Safa, was his illustration of his works close to his teacher's works. He was able to design a hand in a delicate, almost miniature tone that transmitted what he had in mind. The simple and linear drawings of Safa, which were executed using cross-hysteresis and very delicate, can be seen in the textbooks of that period.
In 1945, we are witnessing the first fourcolored book featuring "Dabireh Child" photographed by Mahmoud Javadipour, Zabih Behruz, who was published at the National Bank Printing House. In the 20s and 30s Hijri Shamsi, due to the large boom in the publication of children's books and publications, a group of graduates from the Faculty of Fine Arts, with precise and logical principles and new styles and techniques, portrayed children's books. Among the pioneers of this group are Lily Taghipour, Mahmoud Javadipour, Mohammad Bahrami, Mohsen Vaziri Moghadam, Rasham Arzhangi and Mahmoud Tejarati (AMIN SALMASI, THE SAME: 41-42).

"Lily Taghipour" started painting children's books since 1946 with balloon books and the wedding of the mountain JabarGardabakhan. From the characteristics of her works, she uses linear shadows and simple hachures and attention to indigenous and traditional elements that are also reminiscent of the images of the Qajar era, as well as the tendency to the art of ancient Iranian art (AMIN SALMASI, same, 42). Taghipour continued her work by illustrating the books of Haji Mullah Zulfali (1948) and the first volume of "The Legends of the Ancients" (1950), and at the same time illustrating several textbooks. It was at this time that Taghipour found her special style. Although her works in this period are still influenced by European imagery, her lessons from the academic principles of naturalistic painting, as well as the repeated recourse to foreign sources, are more intrusive and add to her understanding of illustration (QA'INI, SAME: 57- 56). 
Fig1- Lily Taghipour, the Old Myths - 1950 - Sobhi (Internet Source 1)

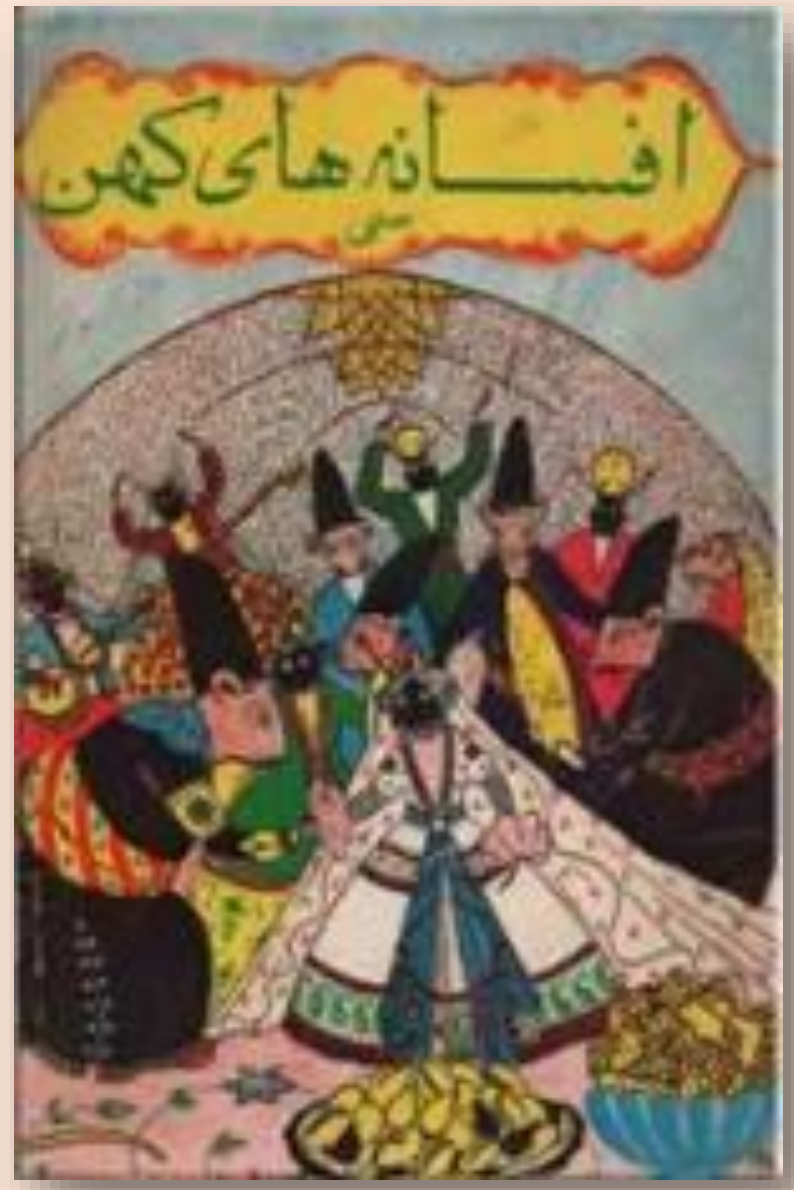

Fig2- Mahmood Javadipour, Mouse and Cat - 1957- Obeid Zakani (Internet Source 2).

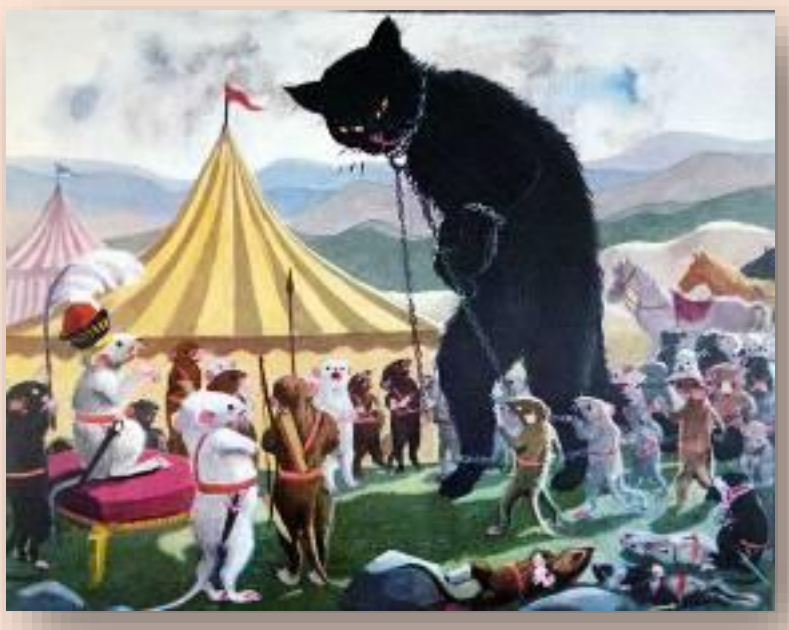

Mahmoud Javadipour is one of the pioneers of this period.

The first book that Javadipour portrayed for children, the book "Dabireh Child" is based on the book by Behrooz (1945). Javadipour after illustrating this book in 1333, the book "Mice and Cats" by Abidzakani, and in 1958 "Stories of Shahnameh" and "The Stories of Ancient Iran" by Ehsan Yarshater, and in 1960 illustrated a few volumes of the series of books "Readings and Chants". These works show that Javadipour is aware of the university's illustrations and is aware of the general principles of painting, such as design, composition and color, has a thorough understanding of the realistic (realistic) and naturalistic (European) styles, it is dominated by various techniques. "Mohammad Bahrami" is another illustrator of this period. The image of the cover of two productions, "The Stories of the Divan Balkh" and "Dekhosh Rabaa", is examples of Bahrami's works. He duplicated "Selected Thousands of Nights" with the selection and rewriting of Shams al-Muluk Mosajeb in 1959 and 1968. He introduces a new look at "Thousand and One Nights" by using some of the elements of miniature painting, such as thin lines and special compositions, and interspersed with some of the elements of European painting, such as perspectives and intense intentions.

Mohsen Vaziri Moghadam, Iranian style painter who was also Mohipour and Javadipoor, was the second volume of "The Legends of the Ancient" (1950), The Stories of the Divan of Balkh (1956), and The Fortress of Intelligence (1954) of the works III illustrator Sobhi Mahdavi. (QA'INI, SAME: 60 $58)$. 
Fig3- Mohammad Bahrami, Selected Thousand One Night 1959 - Shams Al-Muluk Interviewer (Internet Source 3)

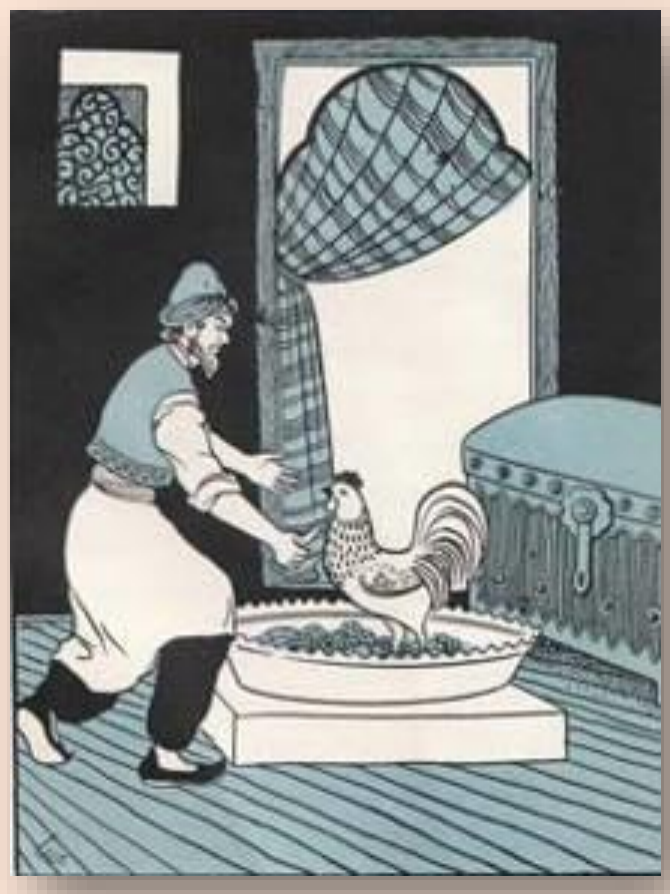

Fig4- Mohsen Vaziri Moghadam, Dekhosh Raba -1956 (Internet Source 4).

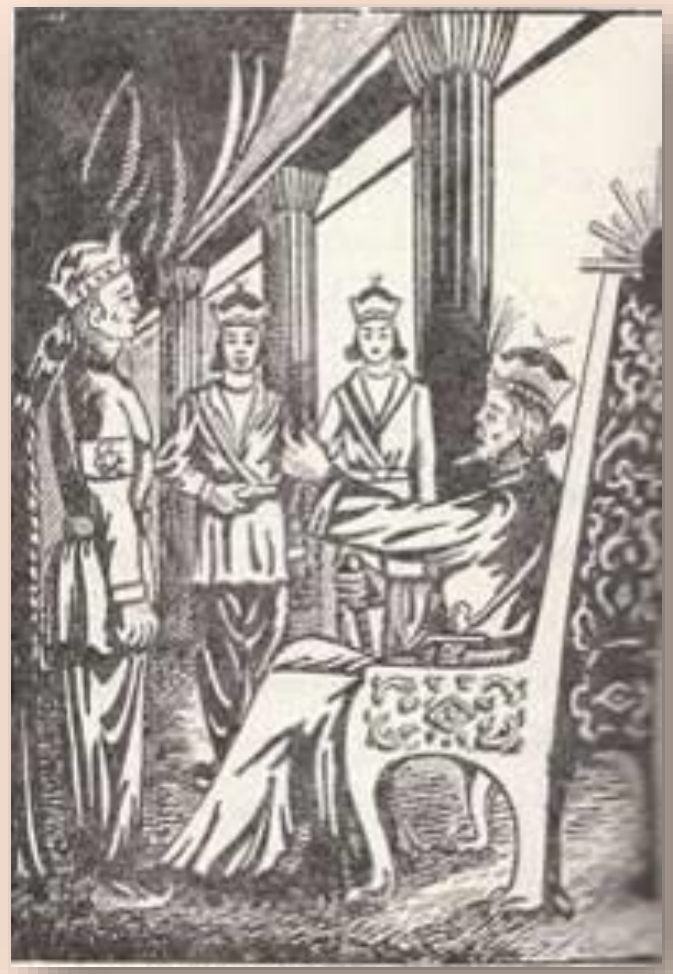

Abbas Yamini Sharif released an alphabet painting entitled "The Game with Alphabet" in 1955. Ismail Wali Zadeh and Abbas Yamini Sharif released the "Toy Story" in 1959, a visual education aid book, at the Kayhan Institute. Among the works of JafarTradechi, a cartoonist and one of the pioneers of animation in Iran, there are a number of books that can be placed in the category of video books. Two books, "The Aunt of the Beetle and the Mr. mouse" (1959), and "The Story of Orange and Bereaview" (1960), depicted in cartoon style and exaggerated form, it has large cutouts and large and colorful images that cover a full screen. In The Story of "The Aunt of the Beetle and the Mr. mouse", the image inside the box is placed on a separate page and narrates the text on the page to the story (The same is the same: 64-63).

In the late 30's, Sokhan Publications, A big step in the direction of printing, Layout, Covering the publication, published in the book "Kado Ghelghele Zan", illustrated by Parviz Kalantari. The cover of this book is hard and it's a big cut, and the technique of the performance is gouache on colored paper. The use of happy and colorful colors, simple designs and great figures is one of the hallmarks of this book. At the beginning of the 40's, in addition to its attitude to indigenous and traditional trends, the tendency toward abstraction and abstract symbols and conceptual art (Conceptual Art), exhibited its first manifestations. The new wave in modern art also became the subject of illustration, and the deconstruction of images of narrative and imaginative images in childish video books became a dominant tendency. As we see in the 60s and 70s, the artistic emergence of works in the field of illustration (AMIN SALMASI, 
SAME: 45).

Sokhan Publishing, in 1961, publishing four books of high quality printing, layout and volumizing, took an unprecedented step in publishing picture books. "Kado Ghelghele Zan " from folk tales, with the rewriting of Manuchehr Anvar, a famous figure in Shahdar Parviz Kalantari and "Butterflies and Rain" by Shahid, by Mohammad Zamani Zamani. Painting technique in both books is gouache on colored paper. "Hassani" The recipe of Farideh Farjam with ilIustration of Gholamali Maktabi is another illustration of the book series of Sokhan Publications. The image technique is a metallic and compound pen that is an illustration with a variety of thin and thick lines, creating color contrasts with sharp and irregular havens in some parts of the image, creating textures with the head of a pen and pouring ink into the foreground areas of the image and putting the color on some parts of the image., In the images created the story and the story needed for the story (SOMEONE, SAME: 65).

With the launch of the Franklin Publishing House in 1958, and the launch of this studio for the preparation and visualization of textbooks, for the first time the central issue for the sustainable ordering of child and adolescent childhood illustrations in Iran will be arranged. "Muhammad Zaman Zamani", "Parviz Kalantari", and shortly afterwards, "Noureddin ZarinKalak" were among the first illustrators of textbooks, gathered at this studio. Then they joined Janet Mikhaili and Gholam Ali Maktabi.

"Mohammad Zaman Zamani" more than others attempted to approach the style of Mohammad Bahrami, who was a strong naturalist. The softness of the design and the lines of good, natural, and solid Bahrami are also reflected in the work of time. In his other books, Gholam Hossein Sa'edi, "The Lost Lips of the Sea" and "Black Dragon" by Jafar Kooshabadi tried to bring new experiences that are not always successful. The timelines in these books are also realistic. Another thing is "Moon in the Nile Valley". The colorful and prolific timepieces of this work have been able to recreate the characters and romantic space of the story. Fig5-Muhammad Time Tunnel - Black Dragon - 1972 (Internet
Source 5).

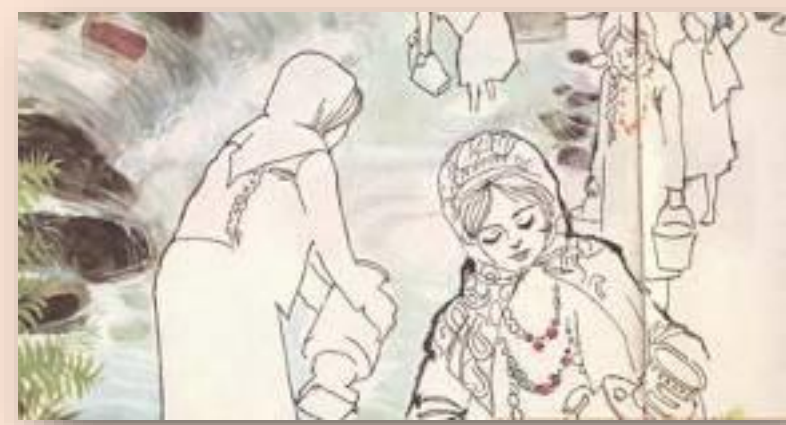

Fig6-Parviz Kalantari - The Flower Comes Spring - 1975 (Internet Source 6).

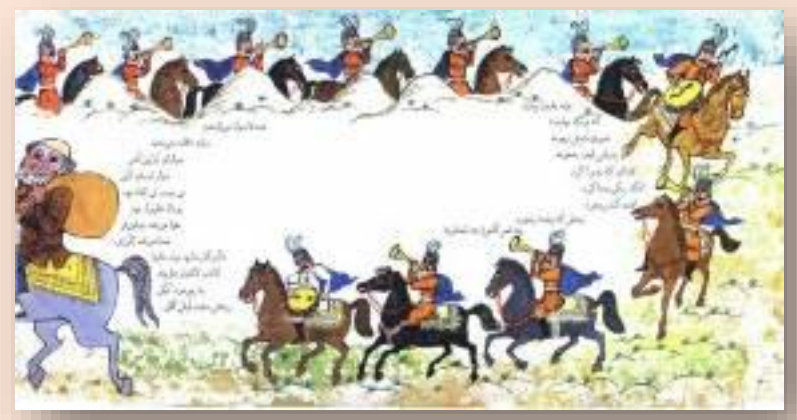

Parviz Kalantari, after experiencing in the textbooks and magazines Peyk, Kado Gelghele Zan and Jom Jamak Barg Khozoun, illustrated. In its works, Kalantari has a special interest in villages and the lives of Iranian villagers. He also wanted to make new 
experiences in this area as well as many of the novice illustrators of this period. For this reason, he tries to blend graphics with elements of Iranian destruction. Kalantari began the work with the children's and adolescent intellectual center with the book "Flower Comes Spring" by Manouchehr Nejadani. The images of this book are a mixture of graphics and elements derived from Iranian paintings, from miniature to drawing a coffee house or a caveman. In this book, he uses childish emotion using flat colors and simplified forms that are labor-like features (THE SAME: 73-69).

The entrance of Morteza Momiz to the world of children's books began with the illustration of the book "Everyone Has a Home" by Lily Ahy (1962) at the Publishing House of the Book Publishing and Publishing Company.

Afterwards, he illustrated the book of the child by illustrating two other books titled "Palettes" written by Lily Ahi (1964) and "Story Story" by Husaymand Fatah Azam (1964). He has made very simple designs in "Everyone's House" and "Story Story " with black lines and obviously designed drawings, and put the color of the flat in parts of the picture, the color of the weather on the pages The book has been created. There is more than one color in each page, in addition to the black color that exists in the door frames, of only one color, but in general, there are four color books. One of the best works for children in this period is the images of the book "Good Tales for Good Kids, Stories from the Quran" (1967) (SAME NUMBER: 78 -75).
Fig7-MortezaMomayes, Selected Stories from Quran Stories 1967- Mehdi Azari (Internet Source 7).

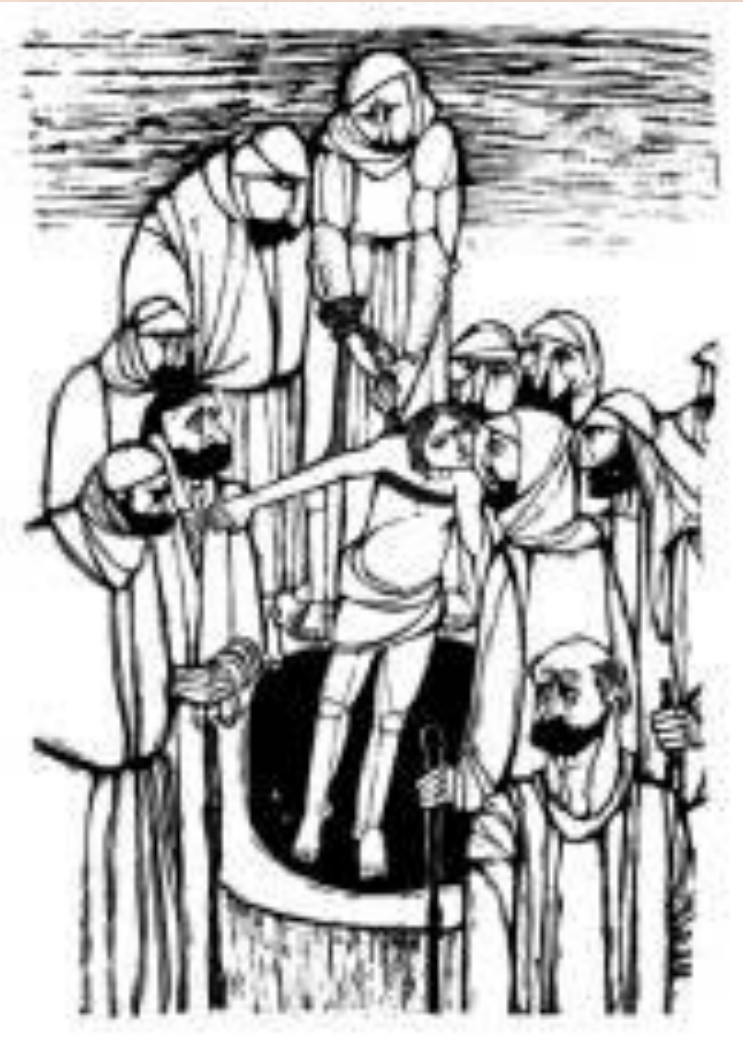

Fig8-Nour Al-Din ZarinKalak, Zal and Simorgh-1970 (Internet Source 8).

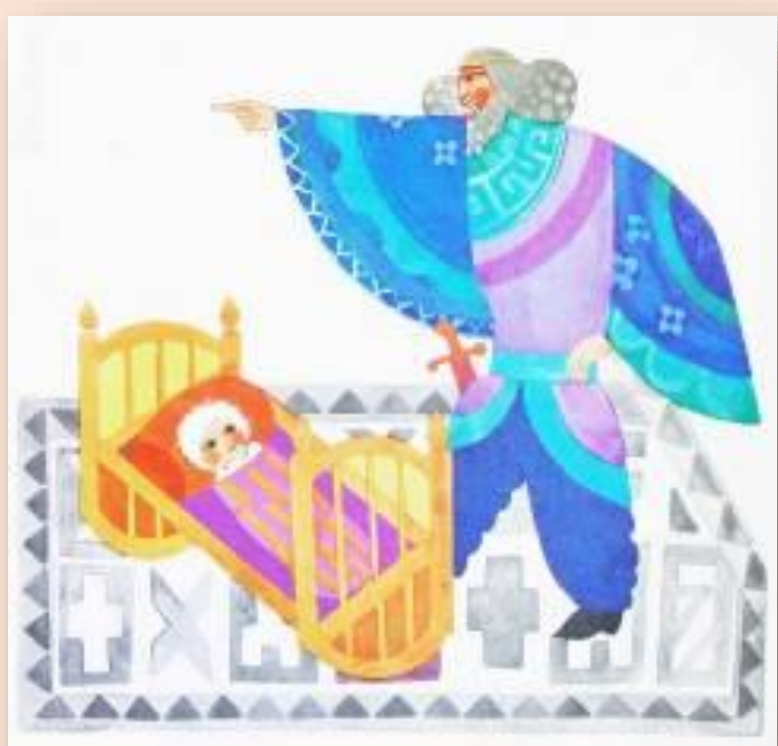


Other famous illustrators of this decade include Farshid Mesghali, Zia al-Din Javid, Alan Biax, Nikzad Ajumi, Nahid Haghighat, Gene Ramezani, Bahman Dadkhah, Morteza Momayesh, Bahram Khayef, Mohammad Bahrami, Mohammad Zaman Zamani, Parviz Kalantari, Nour Al-Din Zarin Kalak and Tony pointed out a few other illustrators. From the famous works of Mesqali, the book is a hero and a blue-eyed boy who is well aware of the abstract tendencies in these works and can be considered one of the leading artists in abstract imagery. The illustration of religious books began with the works of Ali Akbar Sadeghi during this decade. The use of elements of illumination and diatribe and miniature texture that creates special spaces is a feature of his works that is, in most cases, considered by the children of the age groups "B, C, D, E" (AMIN SALMASI, THE SAME: 49-45).

The first achievement of the Atelier Center, the book "Ammunorosis" by FaridehFarghm and M. Azad, illustrating FarshidMesghali, with the aim of creating a new movement in the illustration of the book of the child. Mesghali illustrated the book "Jamshid Shah" by Mehrdad Bahar (1968), with the influence of two ancient and Islamic arts and the use of some mythological symbols. In his visual narrative, he uses delicate but powerful lanes that have been exaggerated in most ways. The composition on the pages is diverse and dynamic. There are several factors that cause more work dynamics: The lines are curved, the various sections of the color, the white of the paper, in the mixing of drawing and drawing, painting and collage, painting and shadows that turn the eye. "Little Black Fish", according to Mesghali, is the first book that was loyal to the space of children and was cre- ated with a new technique. The technique of this book is hand-printed. Style and technique of Mesghali has been integrated since 1971. Among the works of Mesghali in a period that has tended to be surreal or unrealistic, it can be named: "The hero" by Taghi Kiarostami (1971), "The City of Marans" by Fereydoun Hedayatpur (1971), "Blue Man's Son" by Jawad Mojabi (1973) And "My Little Lizard" by Mansoureh Fatemi (1976) (QA'INI: $84-80$ ).

The pinnacle of the book's illustration was from the 50's. Illustration in this period tends to abstraction and imagination. The use of the line element in the illustration and the interest of illustrator artists in figurative design, the presence of techniques such as collage (sticking pieces), variety in handwriting, the simplicity of coloring and the use of Iranian artifacts are the hallmark of illustration in this decade. Farshid Mesghali, Morteza Momayesh, Gholamali Maktabi, Mehrnoush Masoumian, Nouraldin ZarinKalak, Bahman Dadkhah, Nayereh Taghavi, Parviz Kallantari, Mohammad Zaman Zamani, Ali Akbar Sadeghi and Janet Mikheili are among the most illustrious illustrators of this decade. (Amin Salmasi, same: 53).

Nour Al-Din Zarrin Kalak, who started drawing illustrations for children's books with textbooks, joined the work of children at the beginning of his career and began to illustrate children's books. He has illustrated new texts in books such as "Crows" written by Nader Ebrahimi (1970), "The Silkworm Tale" by Nour Al-Din Zarin Kalak (1972), and "The New Years and Days" by Samang Baghcheban (1974). He used fingerprinting techniques in illustrating "The Crows" book, and on the layout of the text, he used visual forms that was unique in Iran. 
The tendency and interest of Ali Akbar Sadeghi to Iran's national literature has been accompanied by him since childhood. The book "The Pahlavan Pahlavanan" is based on an Iranian allegorical story. Sadeghi has referred to the book, illustrating this book as a mix of antiquities, miniatures, and coffee shops, to illustrate the space of life and clothing of the people of that period. But the garments in the pictures are not a garment worn by wrestlers, helmet, armor, and apparel characters are more consistent with the battlefield soldiers. He decorated these decorative forms with coloring parts of every image, especially the orange, red, green, blue and golden colors. In the book "Pahlavan Pahlavan", "Gordafarid" or "Abdul Razzak Pahlavan", images do not have perspective. Characters, such as the Achaemenid artwork, are more of a dream.

In the honest images, the presence of men is abundant. Stout men with very large eyes, continuous eyebrows, thick mustaches, young faces and wrinkles of any age and rank, with stare. The cover of the ghosts of the stories is a martial arts uniform with hat and glittering gloves. In the book Abdul Razzaq Pahlavan (1351), based on a narrative narrative of the life of the Ayarids in the period of the descendants of Changiz, Sadeghi has used the Hashour and color composite technique and in the book "Rounded Up", he used a painting technique on a rainbow and light plywood (QA'INI: 99 -96).
Fig. 9-FarshidMesghali, Jamshid Shah "- 1966 - By Mehrdad Bahar (Internet Source 9).

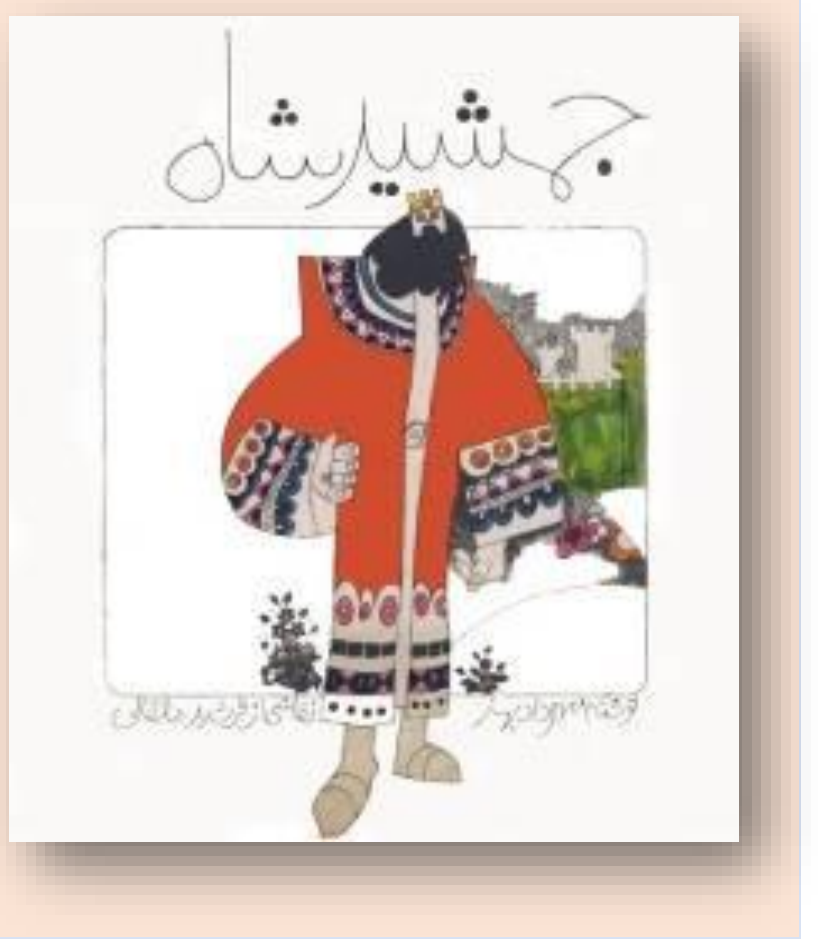

Fig10-ArdeshirMohassess, Untitled, 1978 (Internet Source 10).

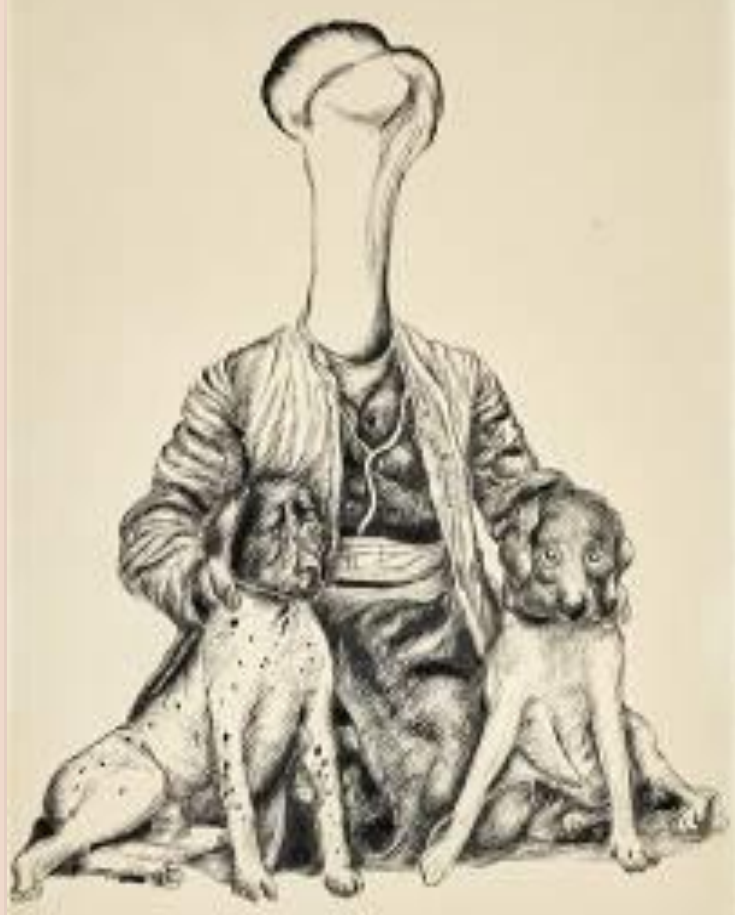


"Ardeshir Mohassess" is one of the artists most noticed as a cartoonist. His image vagrancy, which is conquered by the line, includes topics that point to class distances and oppression in the space and the dirt.

\section{AN INTEGRATED SPACE IN CONTEMPO- RARY IRANIAN PAINTING AND ILLUSTRA- TION}

In the Iranian painting space - painting depicting man and nature was never realistic and natural, but the form and structure of Persian artwork are subjective, purposeful, static and abstract, and the incident presented in traditional Iranian painting was not reflected through simulation. Meanwhile, a group of interested artists influenced traditional and ethnic identity in various ways, including the choice of Iranian themes, had this goal and many of them have Iranian antiquities and architecture and elements that have an Iranian identity, such as carpets and rugs, the ancient legends of Iran celebrated the mourning and even the face of Iranian markets to create their works.

On the other hand, surrealism can be regarded as one of the most important tendencies of Iranian contemporary painting. The first emergence of surrealist tendencies and its relative flourishing can be seen in the second half of the forties. This tendency to adapt to the culture and spirit of the Iranian lyrist, with a tendency and desire to dream and dream in the works of several of his new Iranian artists. This tendency to surrealism and even symbolism, as a broad stream in contemporary painting, continues to evolve. The surrealist artist drives away from the concrete realities of the society, into a foreign and all-out world of fantasies and old and rotten thoughts with an empty statement of any kind of humankind. Surrealism, with all its ups and downs, attracted many artists due to its special features. Sohrab Sepehri, Morteza Katouzian, Iran Droude, Hojat Eshkaqi, Habib A ... Sadeghi, Ali Akbar Sadeghi, Khakdan Unit and Aydin Aghdashloo are among the contemporary artists in this field (GOODARZI, 2005: 111).

\section{Fig11- Sohrab Sepehri, House of Kashan- 1978- Oil on can- vas130x5 / 80- (Internet source 11).}

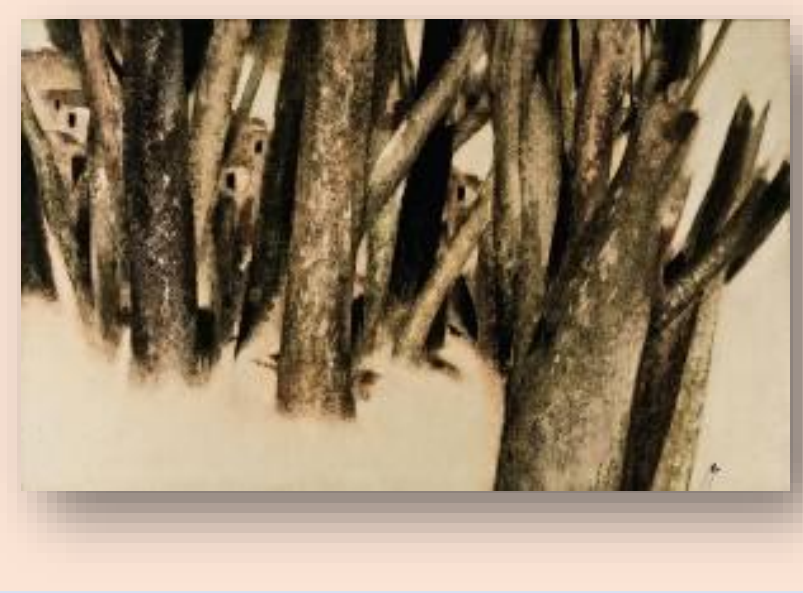

"Ali Akbar Sadeghi" is one of many artists who are involved in both painting and illustration.

Sadeghi is the initiator of a special style in Iranian painting, influenced by cafe houses paintings, iconography, and traditional Iranian portraiture and Qajar artistic style. Master paintings are used by Iranian, Islamic and Western counterparts, who succeed each other in the horizontal axis. They have created works that can be considered on two pillars of thought and vision. In the older works of Sadeghi (both in painting and illustration and in moving paintings), the head of the predominantly Persiandominated Iranian myth is dominant, and the work space with the Herat School paint- 
ing has some unmistakable similarities. In many of these works, elements of the orphanage can be distinguished in their actual form (water, wind, fire and soil) and sometimes in the shade of the main colors of the Persian painting (blue, red, acre / golden and green). The second group of works that make up sadeghi work, overcoming Western myth is evident in them, In these works, with the concept of the cadre (in the concept of Western painting), in contrast to the tabulation in the Iranian painting and contemporary creations of contemporary human beings, the soldiers in the first group take the honest paintings. Of course, even today's shades are dressed in dresses for Achaemenian soldiers and Mithrahi roles. In these works, the character of surreal expression is more than the paintings that dominate the Iranian space. Although Sadiq does not regard surreal as a Western element: "Iranian miniaturists are very surreal in my opinion, and our Iranian mystical imagination is also surreal."

In the third group of honest works, the Persian and Western space will be displayed in a frame; As the painter portrays a dancer portraying Edgar Dega (French painter) in an Iranian painter (Ballerina and Dega boards), or where, with his hat and mustache for the Mona Lisa, a whimsical image of the coexistence of the myth of painting Western creates among Iranian icons (Source 1).

Ali Akbar Sadeghi is one of the most significant Surrealist painters in Iran. Most of his works are full of mythologists who accompany them with national themes. His words emphasize that his work is a blend of Western surrealism combined with mysticism and a kind of Oriental imagination. He also created and performed works with a watercolor technique with the same mythological-Iranian atmosphere. Sadeghi surrealism is often a mixture of satire with poetic spaces (GOODARZI, 2005: 113). Sadiqi has taken a great interest in the iconography of the Qajar era, and he has followed the personality tracing of the traditional way of idealizing the facts. Revealing the characters without using the special features of the decorative designs of the Qajar period is characteristic of this group of works of Sadeghi (QAAENI, SAME: 98).

The symbolic, mythical and legendary forms of Shahnameh are forever part of his paintings. The world of his works is a figurative that resembles old-fashioned miniature paintings with popular forms of art. Ali Akbar Sadeghi, in his paintings, combines rich Persian art traditions with a surreal style of oil painting and, with the extraordinary use of color and form, creates amazing works of great size. He is a master of storytelling and creates stories of his works from various Persian sources, especially historical figures of the Qajar era.

"A human being, when he is born, is a warrior man, only to fight that did not arise," he says. He is crying to the world that means she wants to be bigger, she wants to be a toy, the bigger that is fighting for her love for her homeland, for her ideals, for her ideas, and for the time he dies with death. So, man, not that sword fighter who kills himself, fights to make life and everything better" (SADEGHI, 2018).

The characters of his paintings are in fact the characters of Iranian mythological stories, the soldiers of the queens, demons and fairies, warriors engaged in war, weddings, and all that is found in Iranian stories, myths. Sadeghi has been able to perform them over many years over large canoes. 
The product of honest efforts is the glorious work that can be seen in the tradition of Iranian painting with all its details.

In different galleries, we can review the evolution of the characters of sincere paintings over the years. Sadeghi painters have found different shapes throughout the years. In the "Camouflage" collection, they are all camouflaged and covered in their own way, in the set of "nails" the faces are covered with nails, and in fact the faces are created with nails. The series "Lost in Fame" is his play with contemporary great painters and putting them in Iranian painting situations (Source 2).

He has used apples in his paintings, and each of his siblings has his own particular theme. The red apple is a sign of love, the yellow apple, the sign of observance and the white mark of purity, and blue is a sign of freedom. "I've stolen more than 10,000 apples so far. I can see more watercolors in the water, but if I want to kill 10,000 , I'll put an apple back in front of me, because I find Siberi, in which there are not ten thousand, "he says. Everything has infinite form" (SADEGHI, 2018).

"Mohammad Ali Bani Assadi" is an artist who has been experimenting with various arts in the course of his artistic activities and creations. He has worked in the field of cartoon, painting, illustration and sculpture. His illustrations are full of visualizations and various visual messages, and the creative game of color and form makes the audience of the poets visually appealing. Bani Asadi has depicted close to fifteen poetry books for children and teens, more than any other illustrator to poetry books. The technical feature of Bani Asadi's works should be the use of color in children's books, the use of the line in teenage books, and the preserva- tion of the tone of narrative in his recent works. Bani Assadi has come a busy and busy way of life, and although he has gained some special interest in children's books and interesting comic books in teenagers, the authentic tone of his recent images is a new incident in the illustration of the book of children and adolescents, However, not paying attention to the imaginative details on the corners of the image and the tendency to diversify in his works, he caused the movement of colors from watercolor to gouache, acrylic, collage and even a marker to make his works from the shades He has a lot of colors (MEHRDAD FAR, 2018: 33).

The manner in which Bani Asadi is in painting is so controversial and contradictory in contemporary sense painting that it is difficult for a reader to accept his paintings. In all of his works, preoccupation with decorative motives is a narrative concern. Despite the many colors in the painting, illustration, and even his sculptures, he always puts his bitter bitterness on the audience, just like his caricatures with a black joke. Bani Asadi in this regard says: "Every day I wake up, I'm glad I can see the other day in the world. We are involved with people on the one hand, and on the other hand, we are all in the world, and we have to determine our own duty to this world. For those who do artwork, there should be among these all the wings. For me, art is a language that I can talk about with it and undoubtedly social issues are happening in my subconscious and the source of this bitterness is a feeling that has not left me indifferent to human pain "(Source 3).

He has also lived up to his other contemporaries in the field of illustrating various experiences. According to him, he was impressed by the paintings of the Qajar period 
and the illustration of the lithography books; he was interested in Persian artists by Farshid Mesghali and Ardeshir Mohasses, and in his professional life tried to look like them. Bani Asadi began in the 60s in illustration for children's books of mixed style, a combination of childish, decorative and realistic. In the 70 s and 80 s, the childhood style was a little disconnected, reaching voluminous designs with hawkers and deformed forms. Bani Asadi is approaching painting more than ever at this time. In the book "The Lady of the Thousand Stories" by Fariba Kalhor Bani Assadi combining the spaces, shapes and colors and the use of black and white collages, which borrowed some from miniature paintings, she has a new experience in her work (QA'INI, 2012: 150).

He believes: "There is no lightness in imaging. You are a literary subject. If you have a clear style of literature, you are subject to the same style. You cannot say I have a surrealistic literature, but I want to work on cubism. How do you want to do this? Can you do this? For which audience do you want to do this? Each of them has a different language. Illustration uses all the drawing tools, but it's still functional. It still has a distinct audience, and there is still plenty of talk within itself " (BANI ASADI, 2018).
Fig12- Ali Akbar Sadeghi, from a set of nails-acrylic on cardboard 40x70 (Internet source 12).

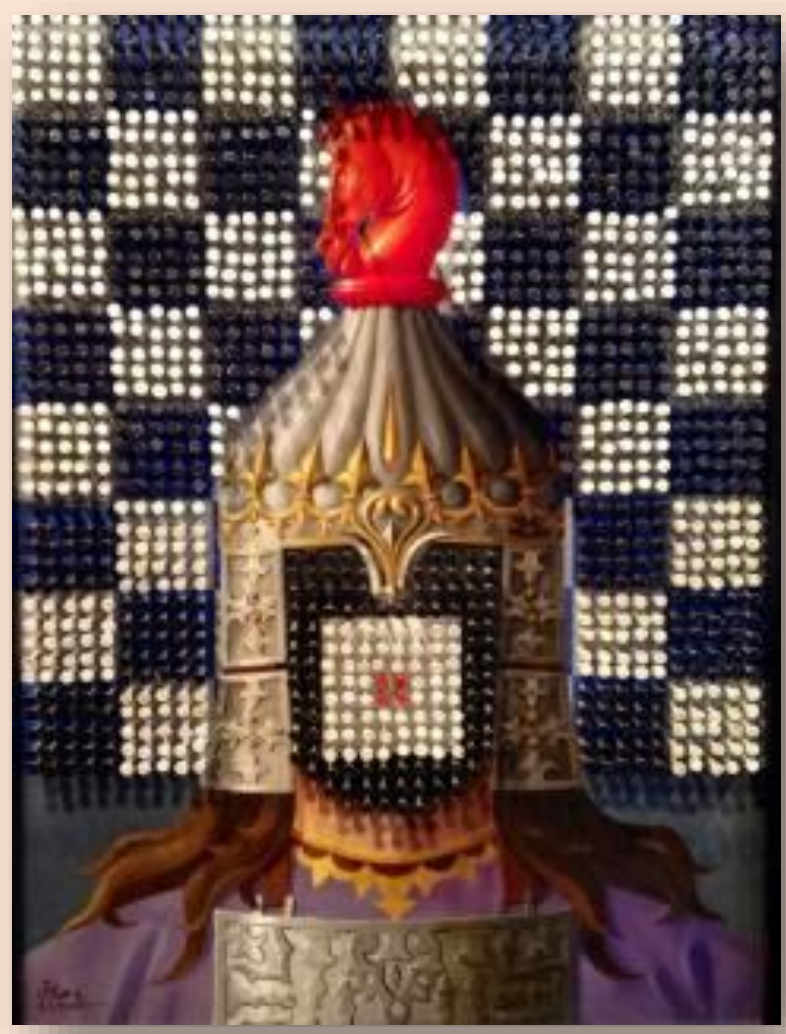


Fig13- Mohammad Ali Bani Assadi - Forty Nights of Thousands 2016 A combinations of lithography and manual and computer designs (Internet source 13).

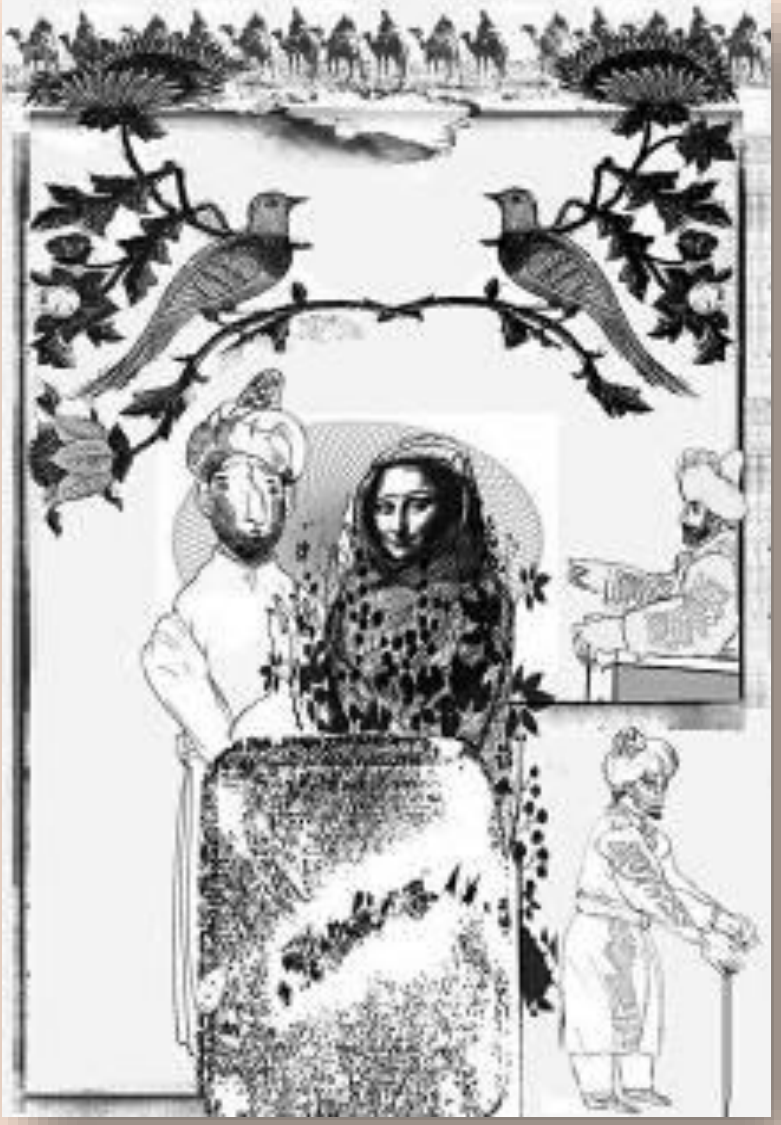

The link that exists between the works of Karim Nasr is the rising boom in all his works, which stems from the inner energy of the artist. Karim Nasr is a painterly figure whose faces can be seen everywhere. He shows us the movements of human organs at a moment of passing or thinking. The greatest movement in his designs and paintings is the inner and inner movement of humans, as far as the "psychological realism" goes. Karim Nasr's approach to painting as "a man," "events," and "emotions" is similar to the behavior of a writer with short stories or a film creator or a social poet with the same phenomena, but it should be noted immediately that what comes from the "palette" of the painter is completely in line with the rules of the visual language (DALWAND, 56).

Karim Nasr demonstrated his ability to illustrate children's books in the 1970s by illustrating a number of children's poetry collections and stories for preschoolers and primary school children. In works such as "Me and the Ducks" by Naser Keshavarz, "Bread and Dew," and "Water, Meat Fish", Kazemi's poetry has been released for teenagers with a simple style, while expressive poetic works have been successful and influential. In these three works, which have a pencil painting, he is sometimes approaching the style of an abstraction for simplicity.

Karim Nasr, who turned to painting in the 1980s, also illustrated several works for children whose sweetheart tales of Ferdowsi's Shahnameh, with his manuprint technique, is very much colored with his childhood paintings of the 70's (QA'INI, 2013: 138).

His paintings and illustrations are full of inspiration. His work is most expressive and plays with coarse pieces. The classical colors of the species sit together, sometimes recklessly with the chunks that are missing here and there, irrespective of what it calls for in the golden square squares.Karim Nasr also told about how to reach this stage and new chapter: "After many years of painting and illustration, when I looked at a different work interval, it came to the conclusion that if this is an illustration, then how the painting should be? Anything else should be something else. I encountered some of my events at some point in the illustration, and I thought more about the difference between painting and illustration. The painting does not have a story; illustration is an 
image part of it outside the image and with literature. He continued. After some time, I concluded that in the painting, my image should not be outside the frame, and only inside the work. I took steps that the viewer faces with them on the board and receives something and understands no story beyond this framework. So I deleted the narrative in some way "(INTERNET SOURCE 4).

Karim Nasr, an Iranian painter in the first half of the 80's created works that, Iranians in the world today display all their complexities, beauties and unique features. The people present in the works of Karim Nasr are busy with mysticism, poetry and television, books and newspapers, sports and politics. Life on the bodies of people, elements and objects in Karim Nasr's works transcends the artist's subjective filter and is recorded in the framework of his designs and paintings (DALWAND, 56).

Farshid Shafiei is a contemporary painter, illustrator and animator. Courage in expressing the image in his works is such that he communicates with the audience very soon. In fact, his work always reads the audience. This simplicity is seen both in the works of Shafi'i painting and in his illustrations. His works are influenced by many artists. Sometimes the poetry of "Chagall" is seen in his works, and sometimes the variety of "Bonader" works or "Matisse" explicitly, or the "Decricot" works, is still confronted with the sketches of the eyes, whether or not the face is a profile or all the appearance and this is one of the characteristics of the painter's paintings, and this feature is also featured in his illustrations. In a period of his paintings he used the elements of painting. The use of archery and horse riding horse racing, as well as the use of Iranian authentic colors such as green, red, yel- low and blue. In some of Shafi's illustrations, only the point element is used, black and white, and has no special color, and some of his illustrations are very simple and designed so that the audience easily communicates with the effect. The use of graphic elements can be seen in the works of Shafi'i Besad (SALMASI, 2018: 59).

Farshid Shafiei has more than any other illustrator tried to use the elements of the visual tradition and culture of Iran to give her works an inspiration. In his images, he used simple and stylishly childish forms, but due to the selection of dark colors and complex combinations with dash lines, he could not publish works tailored to his audience groups. Shafiee has been featured in some of his works such as "Moving: A collection of scientific tales" by Mohammad Reza Shams to simplify the visual elements influenced by illustrators such as Eric Carl. In one of his last works, Jam Jamak Lez Khozoon, Samina Baghcheban (2007), published by Nashr-e-Nazar, has used flat and cheerful colors and visual elements based on traditional Iranian culture. He has also published several works with foreign publishers, among them the "Jacquard doll" published by the French Liberal (2008) and the "Shahrzad" in Spain and "Farshid" in South Korea (QA'INI, 2011: 166-165).

Farshid Shafiei says about himself and his works: "As in the past, these days I do not push myself to get the job out of work, repairing my relationships and removing parts of it, or trying to remove erosion sections, followed by this behavior I'm calm. I do not make anything. I and that thing together we make and go. I have used a lot of designers from the form of appearance. Maybe I started painting with "Chagall", or design from figurative, but at the moment, design- 
ers are less attracted to my attention (Source 4).

Fig14-FarshidShafi'i, Christ and the fishermen-Acrylic on the wood -35 x23 (Internet Source 14).

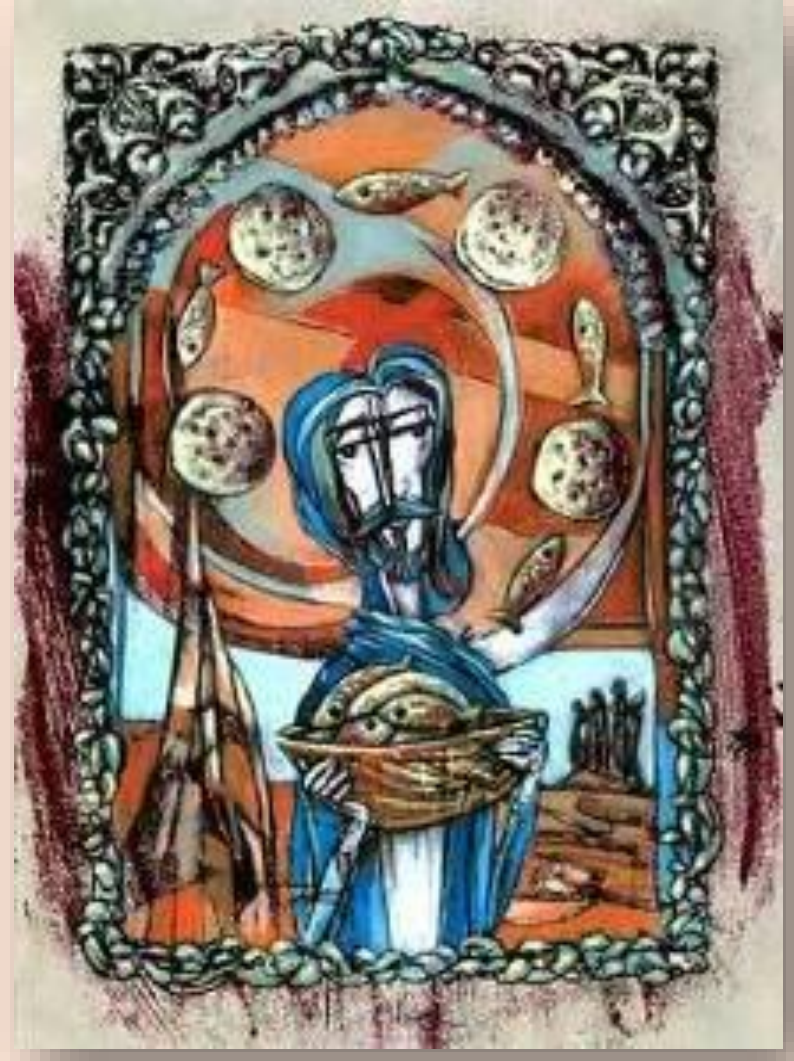

Fig15- Karim Nasr, Sarah-Akrelik smile on fiber- 60x60 -2008 (Internet Source 15).

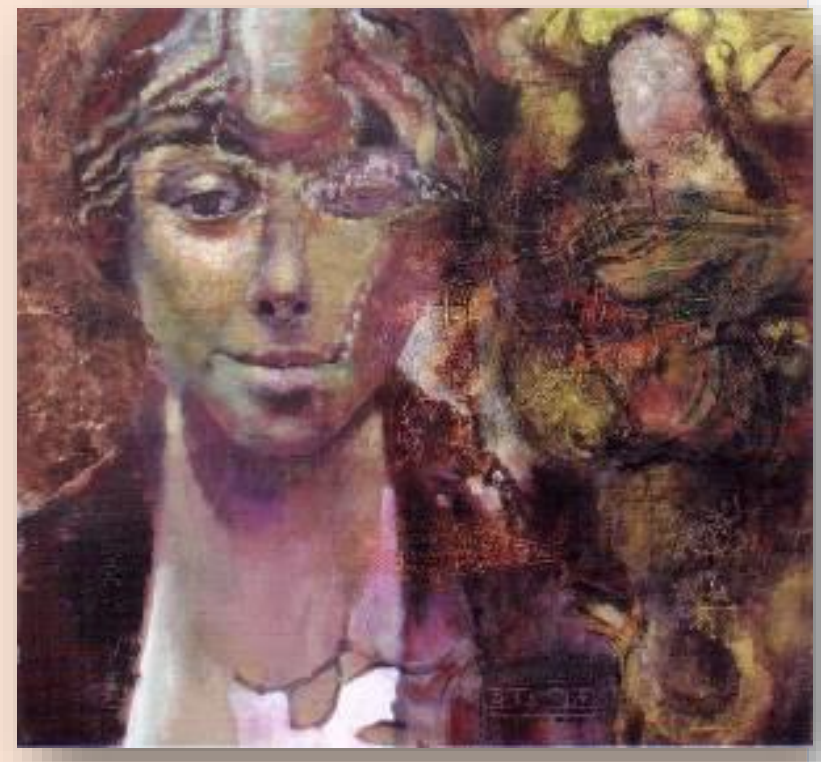

\section{CONCLUSION}

Given the history of illustration in the most ancient times, when human beings began to create images for recording their events and events, we can say that painting is a narrative. The narrator illustrates the text, but there are some differences between painters and illustrators. Today the boundary between these two artistic forms is removed and what matters is the expression of artist's thinking. There are works that are illustrations, but they do not just focus on today's audience and can contain well-known signs and symbols. In the modern art of symbols, the elements represent the reality and through which we can understand the subject.

From my point of view, one of the most important factors for using painting and painting techniques in each other is the artist's angle of view that motivates the artist to create and create an effect. Because 
the artist based on his point of view, owns a point of view on the subject and how to implement his idea and idea.Artistic creativity is considered as another important factor in art. Creativity is used as an innovation, and this is interpreted in the light of a new mentality. Creativity means the ability and ability to create and create a work.

Another important point is the selfconsciousness of the modern artist. Contemporary artist is always aware of various aspects of his work and works very accurately in his work. Modern art is not only dependent on the artist's mind; it depends on other texts and on experiences of different periods. The modern artist does not make his work merely on the basis of intuition and instinct. Creating an effect for her is based on the aesthetic knowledge of the art experience of the past. Some painters and illustrators have influenced the schools or styles of the ancients and presented them in their own way in a modern way. For example, the spaces and elements used in painting, or the technique, and the coloring of the various courses of the school, are inspired by European styles and create their own creativity in a new way. These artists easily break the boundary between arts, sometimes enter the imagery world from the painting space, and sometimes enter the painting space from the age of illustration. Although the images of artists in the 70 's can be seen in free designs and crossshaped hacks, irregularities and deformation of shapes, but in each work, there is also a variety of experiences. Experiences of mixing different styles.

While images are portrayed in the works of artists in the style of expressionism, elements of cubism can be identified.

Some painters have painted in their works and sometimes approach the style of simplicity in the abstract artistic style.

Like the works of Karim Nasr, and sometimes with a happy and brilliant color, and a childish style, yet Expressive, has benefited from combinations that have contributed to the space of the story and its narrative power. Colorful illustrations with many details that have been taken from the ancient tradition of Iranian painting and painting. The narrative style of the images, the color extinction, along with the simple design of the design, makes many works of artists without text too meaningful.

\section{REFERENCES}

AHMADI, BABAK. Haghighat and beauty, First Printing, Tehran, Center Publishing, 1995.

AMIN SALMASI, MEHRDAD.Illustration of history, principles, principles, techniques, First Printing, Tehran, Fakhrakia Publications, 2017.

BANI ASADI, MOHAMMAD ALI.A Conversation with the artist, Fereshteh Fath AliZadeh, Tehran, 2018.

DALWAND, AHMAD REZA. Catalog of the Black and White Periodical Exhibition, 2012.

EBRAHIMI, NADEREH. Introduction to the illustration of the children's book, First Edition, Tehran, Awareness Publishing, 1988.

GOUDARZI, MORTEZA. Painting history of iran from the beginning to the present, First Printing, Tehran, Publishing, 2005.

HOSSEINI, SETAREH. Application of Imaging in Contemporary Painting, Autumn 2012, Tendee Magazine, 2009, No. 238. KASHMIR BREAKER, HAMID. Patterns for contemporary art in Iran today, art of tomorrow, 2010, No 1, 28. 
MEHRDADFAR, MARYAM, Illustration Instrumentation Technique, First Edition, Tehran, Marlik Publishing,2017.

PAKBAZ, ROYAN. Encyclopedia of art, Seventh Printing, Tehran, Farhang-e Mo'aser Publishing, 2009.

PAKBAZ, ROYAN. Iranian Art at a Glance, Spring 2010, Hanrangarda, No. $1+28$.

QA'INI, ZOHREH. Illustration of children's books, definition of history and species, First Edition, Tehran, Cultural Arts and Research Institute of Children's Literature History, 2011.

SADEGHI, ALI AKBAR. A conversation with the artist, Fereshteh Fath Ali-Zadeh, Tehran, 2018.

www.irna.ir/fa/news/82849538/

www.newspaper.hamshahri.org/id/7256

www.honaronline.ir/.../102005/

www.tandismag.com/48027/

www.resistart.ir/content/

http://www.roozrang.com/

https://iranak.org/content-

https://iranak.org/content/126

https://iranak.org/content/6

https://iranak.org/content0/17

https://ketabnak/book/13714

https://www.aftabcomm.org/journal/ardes

hirmohasses-

www.artio.us/artist/aliakbar_sadeghi/artw

ork/nailseries-12

www.atalmataltootooleh.com/178

www.f2dastan.blogfa.com/post/1

www.homaartgallery.com/

www.khabargozarisaba.ir/fa/news/50112

www.mahmoudjavadipour.com/gallery

www.momayez.ir/fa/illustration-

www.uic.blogfa.com/post/55 (c) (7)

License information: This is an openaccess article distributed under the terms of the Creative Commons Attribution License, which permits unrestricted use, distribution, and reproduction in any medium, provided the original work is properly cited.

Article received on February 07, 2019.

Evaluated July 26,2019.

Accepted on August 05, 2019.

Published on August 07, 2019.

How cite this article (ABNT):

KALKHORAN, Fereshteh Fathalizadeh; KAMRANI, Behnam. Study the effect of the painted look in the works of illustration of iranian painter artists. Estação Científica (UNIFAP), Macapá, v. 8, n. 3, p. 71-88, Sept./ Dec. 2018. 